\title{
The Clinician, Germs and Infectious Diseases: The Example of Charles Bouchard in Paris
}

\author{
ALAIN CONTREPOIS*
}

The space of a few decades, at the end of the nineteenth and the beginning of the twentieth century, saw the establishment in France of "la pathologie infectieuse", a new discipline or medical speciality that gave rise to new clinical and laboratory practices and concepts. ${ }^{1}$ Historical studies on this subject have focused, above all, on the theoretical aspects and have tended to attribute a privileged role to Louis Pasteur. The majority of French historians have simply analysed the "Pasteurization" of French medicine and implicitly assumed the validity of this analysis for western medicine and the overall importance of the French hygienist movement, the role of the "go-betweens" of Pasteurism's influence on Pasteurian "know-how" and "network".2 In 1984, Bruno Latour broke with eulogistic historiography, but still maintained Pasteur's central role to the extent that he controlled the network that he had created, that is to say, the mediators between his laboratory, hygiene and the clinic. $^{3}$

But little has been said about these clinicians. ${ }^{4}$ It seems that this way of viewing them, as mere importers of Pasteurian ideas, neglects the fact that these practitioners themselves did laboratory work, using approaches different from Pasteur's, whether they worked on etiology, made use of bacteriological tools and appropriated clinical bacteriology to their own interests, and raised their own questions, not necessarily those of Pasteur's laboratory, in relation to their experiences as practising doctors.

* Dr Alain Contrepois, Centre de Recherche Médecine, Sciences, Santé et Société (CERMES), 182 Boulevard de la Villette, 75019 Paris, France.

\footnotetext{
${ }^{1}$ Among the numerous studies on this subject, see Paul Baldry, The battle against bacteria, Cambridge University Press, 1976; William Bulloch, The history of bacteriology, Oxford University Press, 1938; K Codell Carter, 'Ignaz Semmelweis, Carl Mayrhofer, and the rise of germ theory', Med. Hist., 1985, 29: 33-53; idem, 'Koch's postulates in relation to the work of Jacob Henle and Edwin Klebs', Med. Hist., 1985, 29: 353-74; Andrew Cunningham and Perry Williams (eds), The laboratory revolution in medicine, Cambridge University Press, 1992, pp. 1-13; Alfred Evans, 'Causation and disease: the Henle-Koch postulates revisited', Yale J. Biol. Med., 1976, 49: 175-95; William D Foster, $A$ history of medical bacteriology and immunology, London, Heinemann, 1970.
}

\footnotetext{
${ }^{2}$ See, for example, François Dagognet, Méthodes et doctrines dans l'cuvre de Pasteur, Paris, PUF, 1967; Jacques Léonard, La médecine entre les pouvoirs et les savoirs, Paris, Aubier Montaigne, 1981; Claire Salomon-Bayet, Pasteur et la révolution pastorienne, Paris, Payot, 1986; Lion Murard and Patrick Zylberman, L'hygiène dans la République: la santé publique en France, ou l'utopie contrariée, 1870-1918, Paris, Fayard, 1996.

${ }^{3}$ Bruno Latour, Les microbes: guerre et paix, Paris, A M Métailié, 1984; idem, Pasteur, Paris, Perrin, 1995.

${ }^{4}$ Russell C Maulitz, 'Physician versus bacteriologist: the ideology of science in clinical medicine', in M J Vogel and C E Rosenberg (eds), The therapeutic revolution: essays in the social history of American medicine, Philadelphia, University of Pennsylvania Press, 1979, pp. 91-105.
} 


\section{Alain Contrepois}

All inquiries on the clinical management of infectious diseases primarily revolved around the diagnosis, with the integration of bacteriological tools into a modified form of pathological anatomy. Yet, since Robert Koch formulated his bacteriological postulates to answer clinicians' questions, is it not reasonable to suggest that his school adjusted itself more quickly to the anatomoclinical approach than Pasteur and his disciples, who were more concerned with immunity and prevention? In other words, because medical bacteriology had primarily to respond to the needs of clinical medicine, was it not closer to the bacteriology being developed in Germany than its French counterpart, in those times of fierce nationalism, when the theme of "national genius" was used to bolster the rebirth of patriotism after the disaster of 1870 ?

Furthermore, was there not an implicit affinity for a current conception of modern medicine according to which the "art" of the clinician would be far removed from the "laboratory science" of bacteriology, which was conducted by specialists mastering specific techniques that, as they developed, would become increasingly foreign to the majority of practitioners? This idea can be readily refuted as soon as one takes a closer look. Indeed, what is remarkable about the period 1870-90 in France is precisely that clinical and bacteriological approaches to medicine developed by way of mutual exchanges, each one contributing to the enrichment of the other.

The same wholehearted advocacy of universal "Pasteurization" is also found in the history of medical therapeutics. Most published studies on the French side have focused on treatments with sera and vaccines, ${ }^{5}$ and, on the German side, on the beginnings of chemical therapeutics, when Paul Ehrlich discovered Salvarsan in $1906{ }^{6}$ As a general rule, little attention has been given to the early attempts at chemical therapy with the antiseptics available as the germ theory was being developed. Yet, French clinicians refused to oppose clinical medicine and laboratory medicine, claiming instead the need to unite them. Among these doctors, a French hospital chief physician, Charles Bouchard, stands out as a remarkable figure.

\section{Germ Theory and Nosographic Reconstruction}

Around 1860 in France, before the emergence of the germ theory, clinical medicine was guided by an anatomoclinical approach, based on the relationship between lesions and symptoms, between physical abnormalities and lesions noted at autopsy, and the symptoms and signs observed throughout the illness and recorded at the patient's bedside. Combining observation, palpation, percussion and auscultation, it was possible to identify anatomical "anomalies" in the living patient. Numerous "infectious" and "contagious" illnesses were described according to these criteria and classified, for example by Augustin Grisolle (professor of thérapeutique et matière médicale at the Paris Faculty of Medicine) in 1862, as: "septic poisonings", "morbid secretions", "fevers", or "inflammations".

\footnotetext{
${ }^{5}$ Suggested reading on this subject: AnneMarie Moulin, Le dernier langage de la médecine: histoire de l'immunologie de Pasteur au Sida, Paris, PUF, 1991.

${ }^{6}$ Georges Canguilhem, Idéologie et rationalité dans l'histoire des sciences de la vie, Paris, Vrin,
}

1988, pp. 69-72; J Parascandola, 'The theoretical basis of Paul Ehrlich's chemotherapy', J. Hist. Med. Allied Sci., 1981, 36: 19-43.

${ }^{7}$ Augustin Grisolle, Traité de pathologie interne, 2 vols, Paris, Masson, 1862. 


\section{The Clinician, Germs and Infectious Diseases}

The emergence of the germ theory, around 1870-80, did not cause a total upheaval, but put into a new perspective the anatomoclinical definitions of diseases. The premise of the theory coincided with already known clinical entities, reorganizing and reunifying them from an etiological viewpoint. The concepts of "miasmas", "viruses", "morbid poisons" and other "invisible particles" had been in use for a long time. " "Small granulations" or "ferments", more and more often observed under the microscope within certain tissues, were henceforth considered to be living "germs" actively involved in fermentations and specific illnesses. But for many clinicians of that period, etiology seemed to be one of the most difficult and obscure problems of pathology. In some specific "virulent" diseases (such as smallpox), the causal agent eluded microscopical observation. A pathogenic doctrine, however, began to impose itself: several illnesses were caused by the action of an agent, a "parasitic being", an "animated ferment", a bacterium, which entered the organism and multiplied therein. As long as this proliferation continued, it provoked functional symptomatic disorders, resulting in "infectious disease" such as infective endocarditis."

Charles Bouchard (1837-1915) started his medical studies in Lyons and did his internship in Paris (1861-62) under Louis Béhier. A chief physician at La Pitié Hospital, Béhier defended the experimental method and "positivism", he was familiar with the numerical method and interested in the "natural sciences", chemistry and the strict application of laboratory methods in the clinic. ${ }^{10}$ Among the professors then at the Paris Faculty of Medicine was the distinguished Armand Trousseau, who held the first chair of clinical medicine at the Hôtel-Dieu Hospital. Bouchard worked (1862-65) first at the Charite Hospital under Alfred Velpeau, then in JeanMartin Charcot's ward at the Salpêtrière Hospital, where he returned to do a second year (1864-65). Like Charcot, Bouchard was familiar with the English and German scientific and medical literature. According to Paul Le Gendre, "Charcot found in Bouchard a resident who was already accustomed to using a microscope and to the detailed examination of patients, and their collaboration was close and productive"." Completing his doctoral thesis ('La pathogénie des hémorrhagies cérébrales' [The pathology of cerebral haemorrhages]) in 1866, Bouchard became interested in the tuberculosis controversy deriving from Jean-Antoine Villemin's work in 1867. In the same year, Béhier was nominated to the third chair of clinical medicine and Bouchard returned to finish his training in clinical medicine under him (1868-70). So, Bouchard the student learned the anatomical-clinical tradition, its French roots and application to nosology.

In 1869, Bouchard became a fully certified medical doctor and Béhier succeeded Augustin Grisolle to the first chair of clinical medicine (Grisolle himself had succeeded Trousseau in 1864). During his training with Béhier, Bouchard was responsible

\footnotetext{
${ }^{8}$ On this question, see Nancy Tomes and John Harley Warner, 'Introduction to special issue on rethinking the reception of the germ theory of disease: comparative perspectives', J. Hist. Med. Allied Sci., 1997, 52: 7-16.

${ }^{9}$ Alain Contrepois, 'Towards a history of infective endocarditis', Med. Hist., 1996, 40: 25-54.
} 


\section{Alain Contrepois}

for laboratory research: microscopy, histology, haematology, chemical analyses (especially urine) and pathological anatomy. During the same year, 1869, Bouchard agreed with Villemin's arguments concerning the "contagion of consumption". He knew the publications of Carl Wunderlich, Carl Rokitansky and Felix Niemeyer on this subject. Wanting to gather more information on German science and to meet Rudolf Virchow, he went to Berlin when Sigismond Jaccoud, Charles Adolphe Würtz and Germain Sée were translating the works of German authors into French. ${ }^{12}$ In 1870, Bouchard became head of the Bureau Central de l'Assistance Publique and, in 1872, assistant professor under Jean-Baptiste Bouillaud, who held the second chair of clinical medicine. In 1874 , as a member of the hospital staff, he held the position of Director of Wet Nurses, before moving to the Bicêtre Hospital (1876).

At that time, the theory of fermentation converged with the theory of parasitism: contagious and infectious diseases resulted from a fermentation, whose active agent within the organism was the "microzoaire", the "microphyte", or again, the "bacterium", the "vibrio", the "bacteridium" (motionless under the microscope), the "spirillum" (if the filament was helical) or the "spore", all of these names designating diverse forms of germs. In 1872, Georges Dieulafoy, Trousseau's intern, distinguished three categories of infectious and contagious diseases: (1) "clearly parasitic" diseases, or due to fungi (scabies, trichinosis, thrush, ringworm, etc.); (2) "septic affections" resulting from the rapid multiplication of "proto-organism-ferments" in the body, producing, according to the case, more or less severe poisoning of the affected subjects (septicaemias, puerperal diseases, typhus, etc.); and finally, (3) "virulent" diseases, sometimes closely resembling septic affections (smallpox, etc.). ${ }^{13}$ This represented an attempt to classify diseases by etiology.

The question of the patient's "receptivity" was also raised during the 1870s, but was not new; it remained wrapped in shadows and mystery whose individual variations were elusive. This question of individual predisposition dominated all pathology, regardless of whether the illnesses were specific or not. And doctors openly admitted their ignorance on this subject. How was it possible to understand such wide disparities of reactions among persons when exposed to the action of a germ? How and why did these "animated parasites" invade one organism and spare another, even when the latter had been the more exposed to the action of the germs? All these questions preoccupied doctors because they could not answer them.

Certainly, two things were generally considered: "the seed and the soil". A principle of infection or contagion was required, but subjects also had a variable tendency to become infected. This "morbid receptivity" was a particular property of the individual which rendered him sensitive, at a given moment, to infection or contagion. For Georges Dieulafoy, some individuals were resistant to the action of viruses and could expose themselves with impunity to contact with the virulent principle; this "immunity" could be complete or incomplete. Some people were completely refractory

\footnotetext{
${ }^{12}$ Ibid., pp. 71-7.

${ }^{13}$ Georges Dieulafoy, De la contagion, Paris, A Parent, 1872, pp. 118-23.
} 


\section{The Clinician, Germs and Infectious Diseases}

to infections, others suffered only slight manifestations of the disease. ${ }^{14}$ This "immunity" was intriguing: certain individuals were resistant not only to contagion but also to the direct inoculation of the viruses. This mysterious receptivity did not seem to be a direct reflection of the individual's apparent strength or weakness. But over time, the immunity could also "run out", with the individual finding him- or herself receptive or again susceptible, for example, to a new bout of typhoid fever. These strange observations fitted imperfectly into the framework of "parasitic theories". Things were not simple and clinicians often had many diathetic types that they confidently ascribed to individuals and these were important in diagnosis and prognosis.

During these years, doctors interested in germs and viruses seem to have been struck by the disproportion between a possible cause, insignificant in appearance and often imperceptible, and its terrible effects. ${ }^{15}$ How could these causes which were so "light" generate consequences so disastrous? The individual could be contaminated by the "smallest inoculum of virus", so tiny that it escaped detection by the senses and medical investigation, and yet this "virulent atom" was enough to upset profoundly the organism or even to destroy it. The virus or germ introduced itself without the person being aware, clandestinely and without pain, leaving no evidence of its passage for a while, then manifesting its presence and its action by a whole series of disorders and events of varying degrees of severity. The entire organism could be invaded: the skin, blood, as well as internal organs. Doctrines clashed in their attempts to explain such phenomena, or tried to combine various theories of germination and fertilization, fermentation, and accounts of animal and vegetal parasitism. In fact, there were different germ theories of specific diseases being debated in specific communities and places in the 1870 s. $^{16}$

Émile Chauffard, professor of general pathology and therapeutics at the Paris Faculty of Medicine (1870-79), complained in 1877 that the germ theory was "simplistic", "fashionable" and "invading". He stated, "It seems to have already conquered the entire class of specific illnesses, the majority of nosology, and tends obscurely to win over residents, who until now seemed to have avoided specificity. The pathology of fermentations has haunted and seduced doctors' minds for many years". ${ }^{17}$ What struck Chauffard in the germ theory was that "the activity which creates the disease", and which up to that time resided in the ailing human organism, became, with the theory of germs, entirely attributed to the latter. This displacement of morbid activity seems to have disturbed Chauffard's conceptions. He was willing to accept the idea that the action of a micro-organism is limited to making a "morbific impression" on the individual that is powerful because it is slow; and that this impression, by affecting the "vital sense", provokes the eruption of the specific

\footnotetext{
${ }^{14}$ Ibid., pp. 32-9. The origin of the term "immunity" that, since the middle of the nineteenth century, designates "the ability to resist often diseases that surround man" or "the ability not to contract certain diseases or to contract none" is clearly described and analysed in the book by Anne-Marie Moulin, op. cit., note 5 above, pp. 22-7.
}

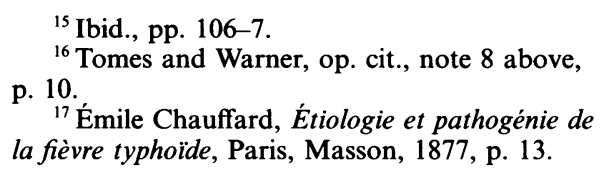




\section{Alain Contrepois}

illness. But this scenario would have absolutely nothing to do with the multiplication of germs.

Therefore, much too quickly according to opponents like Chauffard, "parasitism" replaced the older concepts of certain spontaneous illnesses. Many doctors participated in this development, others looked on, surprised or critical. And yet, the etiology and pathogenesis of specific illnesses seemed, at least in the eyes of many doctors, to become easier to understand with the help of the germ theory. Furthermore, it was a true case of "popular success" denounced by the critics. These latter protested against "the prospectuses, which enthusiastically boasted about the properties of this or that parasiticide" intended to cure certain fevers, and against simplistic popularization of the topic. ${ }^{18}$

But, here again, things are not simple. Microscopical observation and bacteriological techniques were far from identifying a germ for each specific illness, whether virulent or not. What was the cause, for example, of typhoid fever (whose micro-organism was not to be discovered until 1880 by C J Eberth)? In 1877, Bouchard reported his ideas on the etiology of typhoid fever to the International Medical Congress in Geneva. He listed chronologically opinions concerning this illness as follows: septic illness, zymotic illness, parasitic illness, contagious illness, virulent illness. For Bouchard it was a specific contagious illness, caused by a still unknown ferment or a virus. While on the staff at the Bicêtre, he noted that, "If the virulent matter does not possess the morphological characteristics of a living being, it none the less is endowed with this strange power that enables it, with the aid of living matter, to create molecules that are similar to it, and recognizable as having the same physiological activity and also capable of indefinitely reproducing similar specific molecules". ${ }^{19}$

It had been observed that contagion occurred exclusively by contact with the faeces of people infected with typhoid fever. Contagion could be passed on by soiled hands and/or clothing, contaminated drinking water or milk (this contamination could be caused by washing the milk buckets with dirty water, or by the dairyman's hands). According to Bouchard, there was no contradiction between contagious and infectious phenomena in typhoid fever. The germ was equally capable of developing both outside and inside the organism. "The germ, finding itself in a putrid household, can thrive there; from there it can pass into a human body and cause illness by multiplying itself; it can then pass from a sick individual to a healthy organism. This concept is only a hypothesis." 20

Without contradiction, infection and contagion would therefore be explained by a single cause: an infectious illness, when the germ originated in a putrid household; a contagious illness, when the germ had already passed through a living organism. This concept could explain small epidemics, sporadic cases and so-called spontaneous cases. Bouchard remained cautious, and considered that, before discussing this germ, it was necessary to demonstrate its existence and to attempt to cultivate it. Once the

\footnotetext{
${ }^{18}$ Ibid., p. 57.

${ }^{19}$ Charles Bouchard, Étiologie de la fièvre typhoïde, Paris, Savy, 1877, p. 16.
}

${ }^{20}$ Ibid., p. 17. 
"morbific agent" was discovered, then the experimental pathophysiology of typhoid fever could be studied.

On 30 April 1878, at the Academy of Medicine of Paris, Louis Pasteur presented a paper on 'Germ theory and its applications to medicine and surgery'. ${ }^{21}$ This interpretation of disease as a coherent entity, in which lesions and symptoms were linked to an etiology, incited more attempts to reproduce experimentally septic and virulent illnesses in the laboratory. The idea that living germs could be involved in certain illnesses also led to revisions and modifications in the interpretation of existing clinical entities. This type of work, involving the reconstruction of categories and the classical tasks of medicine (this time based on etiology, which became a central element), was not a primary task for the Pasteurians. During this period, whole fields of pathology were nosographically re-evaluated, in parallel with the development of a burgeoning bacteriological medicine. Bouchard's educational and early clinical experience came at a time when Claude Bernard's physiology was ascendant, and when Pasteur's early work on germs and Lister's focus on antisepsis was leading to new thinking about infection.

\section{The Laboratory of Bacteriological Diagnosis}

At the end of the 1870s, Bouchard, as we have seen an inveterate reader of both French and German clinical research, sought to link his medical practice with the new approach to the etiology of infectious and contagious diseases. He intended this nosographic reconstruction to serve as a diagnostic aid. He closely examined the cases and the systematic search for germs in different diseases and found fault with the axiom: one germ - one disease. In fact, to the concept of morbid entities caused by the same specific microbes, another, less "simple" one had to be added: apparently identical morbid processes, at least in terms of their first manifestations (such as sore throat, meningitis, endocarditis, bronchitis, etc.) could be provoked by different germs or by the association of several germs.

Bouchard was particularly interested in the microscopical examination of various samples taken from the patients in his care. He spent his mornings at the Bicêtre Hospital and, between 1876 and 1879, set up an embryonic laboratory with limited funding. ${ }^{22} \mathrm{He}$ had as residents Jacques Doleris (1876), an enthusiast of "microscopic research" (who became very involved in the bacteriological culture of blood around 1880) and then Arnold Netter (1879), who expressed a preference for laboratory research without neglecting clinical medicine. From this period onward, that is to say ten years before the course in "technical microbiology" started at the Institut

\footnotetext{
${ }^{21}$ Louis Pasteur, 'La théorie des germes et ses applications à la médecine et à la chirurgie', Lecture faite à l'Académie de médecine par $\mathbf{M}$. Pasteur en son nom et au nom de MM. Joubert et Chamberland, le 30 avril 1878, Paris 1878, Euvres de Pasteur réunies par Pasteur ValleryRadot, 7 vols, Paris, Masson, 1922, vol. 6.

${ }^{22}$ Le Gendre, op. cit., note 10 above, pp. 202-9. This precociousness in terms of
}

\author{
bacteriological analyses in the laboratories at the \\ Paris Faculty of Medicine is even more \\ remarkable because subsequently, once the \\ courses began at the Institut Pasteur, it was \\ progressively swept under the carpet, despite \\ lectures being given in this field, notably in the \\ laboratory of the professor of experimental \\ pathology.
}




\section{Alain Contrepois}

Pasteur, Bouchard and his residents carefully examined under the microscope various tissues and fluids taken from the organism: the expectorations of tuberculous victims, searching (in vain) for the germ suggested by Villemin's experiments; urine, searching for the germs of urinary infections, blennorrhagia and typhoid fever. ${ }^{23}$

On 25 September 1879, Bouchard left the Bicêtre for Lariboisière Hospital, where he was to remain for twelve years (the successor to Chauffard, he was professor of general pathology and therapeutics at the Paris Faculty of Medicine, 1879-1910). An annex to the men's ward was set up as a laboratory, where he and his residents examined specimens under the microscope and performed urine analyses. This small room was cluttered with glass tubing, test tubes, funnels and jars, and a bed for the patient to use while samples were being taken. Each patient's urine, regardless of the illness, was collected every day, sent to the laboratory and subjected to chemical and microscope analyses. Bouchard and his residents sought to verify the major principles, widely discussed at the time, of penetration through the pharyngeal crossroads of the "microbial poisons" implicated in infections of the tonsils and nephritis of tonsillar origin. They also sought to localize infectious agents and their poisons in certain fluids, and in the arthropathies during infectious or toxic states that Bouchard named "pseudo-rheumatisms".

In Bouchard's department, every time a purulent abscess or effusion appeared suddenly, the resident had a standing order to drain the liquid or the abscess without delay. If this drainage presented operational difficulties, a nearby surgeon was to be called as soon as possible to do it. For Bouchard, a laboratory was a workplace with supplies and instruments, and also a place to meet with his collaborators where different approaches to illness could be formulated and discussed. ${ }^{24}$

To set up the laboratory for bacteriology, he called upon a student, Louis Capitan, who experienced great difficulty in obtaining the precise indications on the instruments necessary for the preparation of culture media from Pasteur's laboratory in the rue d'Ulm. $^{25} \mathrm{He}$ finally obtained the information from the Parisian firm Wiesnegg and Lequeux, manufacturers of medical equipment. An incubator with a constant temperature and an autoclave, made by this firm, were installed. With Wiesnegg and Lequeux, Capitan and Bouchard devised a coiled apparatus capable of supplying boiling water almost instantaneously. A workman from another manufacturer advised Capitan on the best glass instruments. From the high storage cupboards with metalwork doors which had been used to house the skeletons of the École Pratique, they made animal cages by inserting shelving and partitions to form different levels and compartments. But Bouchard had to wait quite a while for funding to obtain histological staining materials.

\footnotetext{
${ }^{23}$ Among those residents who made their mark in Bouchard's laboratory were also: Albert Charrin (who, along with Henri Georges Roger, discovered in 1889 the agglutination of bacteria, a phenomenon that serves as the basis of serological diagnoses), Louis Capitan, Augustin Gilbert (who replaced Landouzy in 1902 as professor of therapeutics at the Paris Faculty of Medicine and replaced Dieulafoy as
}

\author{
professor of clinical medicine at the Hôtel-Dieu \\ in 1910) and Henri Georges Roger (in 1895, \\ staff physician at public hospitals and head of \\ the laboratory of general therapeutics and \\ pathology, and, in 1904, he replaced \\ Chantemesse as professor of comparative and \\ experimental pathology). \\ ${ }^{24}$ Le Gendre, op. cit., note 10 above, p. 203. \\ ${ }^{25}$ Ibid., p. 203.
}




\section{The Clinician, Germs and Infectious Diseases}

Experimental research had, in his opinion, refuted false theories, rounded out inadequate doctrines, clarified obscure points, but it had not "shaken the edifice" based on the observations of clinicians. Bouchard was convinced that clinical and experimental medicine should be united rather than opposed. The "pathologie infectieuse" was not based solely on bacteriology. The reorganization was more general and more complex, in continuity with long-standing anatomoclinical knowledge. The clinicians associated a "germ" with the signs, symptoms and lesions detected on the living patient. Progressively, a clinical symptomatology of "infectious diseases" was elaborated, diagnostic procedures evolved, techniques for sampling and "tracking" the germ (which implied new tools and new approaches) were perfected, all in parallel with the development of bacteriological techniques to isolate and culture germs.

For example, following the lead of Wunderlich in Germany and Jaccoud in France, highly detailed studies of temperature curves were conducted. ${ }^{26}$ Doctors gained valuable insights from these in terms of diagnosis and prognosis. Examination of temperature curves, associated with other clinical symptoms, led to the search for particular germs in fluids or tissues. Clinical practice focused on the systematic search for signs accompanying "fever": shivering, elevated respiratory and cardiac rates, sweating, increased size of the spleen, the appearance of the tongue, swollen glands, etc. Clinical observation, the comparison of "morbid processes", and consideration of the conditions of their appearance were the elements on which doctors based their presumptions of the infectious nature of an illness. Bacteriology added an element of certainty or strong probability to the diagnosis.

The idea of submitting the clinical diagnosis to the "verdict" of a bacteriological examination progressively took hold at the end of the 1880s and into the 1890s: this new way of approaching illness modified clinical practice and its relationship with the patient's body: he or she was "inhabited" by microscopic germs which circulated and proliferated. The invisible evil, coming from outside, could progress in the essential fluids of the body and insidiously eat away at the individual. From then on, germs were "tracked" by taking samples at the patient's bedside from the throat, sputum, blood, pleural and spinal fluids, etc., with which the culture media were seeded. This was the era of perfecting "blood cultures", later to be called haemocultures, which also implied technical innovations (the invention, for example, of a syringe that could be completely sterilized), ${ }^{27}$ the perfection also of "spinal" or lumbar puncture. ${ }^{28}$ These sampling techniques, performed under sterile conditions by clinicians at the patient's bedside, permitted immediate bacteriological evaluation.

This approach is truly at the heart of clinical medicine. Just as there are techniques for observing lesions, there are also techniques to divulge the causal agent. New concepts, new skills, new equipment, and a new relationship between clinical and

\footnotetext{
${ }^{26}$ Carl Wunderlich, De la température dans les maladies, French trans. of the second ed. (1870), with Sigismond Jaccoud's introduction, Paris, Savy, 1872.

${ }^{27}$ Alain Contrepois, 'Naissance de l'hémoculture', La Revue du Praticien, 1995, 45 (8): 942-7.
}

${ }^{28}$ Idem, 'Traquer le germe', Pyrexie, 1997, 1 (5): 28-9. 


\section{Alain Contrepois}

laboratory medicine became established in a more or less improvised manner within the very same hospital department. This laboratory was not a Pasteurian laboratory. In this place, the work could be seen as a routine microscopical pathology, an extension of the clinical gaze. But this laboratory was also a place for diagnostic analysis. Here again, the tools used were above all those of German bacteriological medicine: Koch suggested the use of solid media, which would allow pure bacterial cultures to be obtained easily; he perfected special instruments for working on these media: platinum handles and loops, etc. But what particularly marked the French clinicians was the discovery of the tuberculosis bacillus (Koch, 1882). As of 1883, Bouchard and Dieulafoy (chief physician at Saint Antoine Hospital) encouraged their residents to search for the bacillus in the victims' sputum samples. ${ }^{29}$

Sputum examination and the search for the tuberculosis bacillus was also of great service to private practitioners. The presence of the bacillus enabled the practitioner to confirm the diagnosis of pulmonary tuberculosis early on. The search for the bacillus was, according to authors of the period, "of capital importance and gives a pathognomonic sign there where auscultation does not allow the presence of tuberculosis to be affirmed" ${ }^{30}$ If this germ was found, then isolation could be prescribed at an early stage, perhaps avoiding the transmission to other members of the family.

For sore throats, it was proved that the clinical signs had an illusory value from a diagnostic point of view, and that only the bacteriological examination enabled the identification of the microbe responsible for the disease: diphtheria bacillus or other germs (streptococci, pneumococci). In the former case, the anti-diphtheria serum was administered immediately (from 1894 onwards). In the others, local antiseptic treatment sufficed. Search for tuberculosis bacillus in sputum and diphtheria bacillus in pseudomembranes constituted crucial aspects of public health.

Numerous discussions and debates took place at the end of the century at the Academy of Medicine of Paris on the subject of diagnosis and the nosological classification of sore throats. According to Dieulafoy (professor of medical pathology, 1886-96), the actual and complete diagnosis of a sore throat, the one determining prognosis, prophylaxis and treatment, entailed assigning a specific etiology to the symptoms. ${ }^{31}$ The anatomoclinical classification of non-diphtherial sore throats was not invalidated but rather completed. The different clinical forms of sore throat were not associated with a single infectious agent, and equally, a single germ seemed to be able to give rise to different forms of sore throats. Clinical observation, therefore, retained its important role: a red pharynx, swelling of the tonsils, sometimes oedema of the pillars of fauces, the appearance of a veil or a uvular aspect, the presence of a "creamy white coating", etc. It situated the sore throat within the anatomoclinical classification and constituted the foundation for diagnostic and etiological procedures.

\footnotetext{
${ }^{29} \mathrm{Idem}$, 'La tuberculose, une maladie infectieuse pas comme les autres', in A M Moulin and A Contrepois (eds), De l'hospital des Incurables à l'hopital Laennec, Paris, Hervas, 2000, pp. 68-81. See also John A Mendelson, 'Cultures of bacteriology: formation and transformation of a science in France and
}

\author{
Germany', PhD thesis, Princeton University, \\ 1996. \\ ${ }^{30}$ Robert Wurtz, Précis de bactériologie \\ clinique, Paris, Masson, 1897, p. 141. \\ ${ }^{31}$ Georges Dieulafoy, 'De l'angine diphtérique \\ à forme herpétique', Bulletin de l'Académie de \\ Médecine, 1895, 33 (session of June 11): 600-8.
}




\section{The Clinician, Germs and Infectious Diseases}

The laboratory therefore became a necessary auxiliary to clinical medicine and associated diagnostic and experimental research. It was the melting pot of diagnostic, pathophysiological and therapeutic studies directly linked to the clinical observations of patients treated in the department. Here we are a long way from the "pure" research laboratory far from the patient. With bacteriological examinations, the clinic-laboratory association became particularly close. This collaboration commanded a large consensus at the end of the nineteenth century. Dieulafoy and Bouchard proclaimed that bacteriological diagnosis made in the laboratory was the true extension of clinical medicine. The clinic became coupled to the laboratory, without the latter edging out the former.

At the same time, Bouchard, influenced by Bernard's ideas on vitalism and mechanism, as well as the great physiologist's studies of the vaso-motor centre, articulated during the first years of the 1890s a theory of infection and immunity that lay between French cellular and German humoral interpretations. ${ }^{32}$ This showed how a clinician like Bouchard interpreted the effects of microbes on the body. This is another claim for Bouchard's general intellectual debt to his estranged neighbours, as opposed to his closer pastorian ones. In his book, Actions des produits sécrétés par les microbes pathogènes (1890), the references concerned especially German authors such as Karl Flügge, Ottomar Rosenbach, Rudolph Nissen, Edwin Klebs, Hans Büchner and Vladimir Wyssokowitsch. ${ }^{33}$

At the beginning of the twentieth century, "infectious diseases" were classified; they became a class of morbid entities in their own right. In 1903, Bouchard declared that modern research on etiology had only slightly modified previous concepts based on anatomoclinical medicine and, in the majority of cases, had in fact confirmed them. ${ }^{34}$ Numerous diseases had been individually identified before the discovery of microbial agents. The discovery of Koch's bacillus nevertheless gave a strong basis to the earlier concept of tuberculosis and linked less precisely identified lesions to it. Despite its demonstration of pathogenic agents (mostly by the German school), clinical bacteriology was not yet able to provide a solid basis to rectify nosography. Bouchard insisted, "Whatever their importance, experimental discoveries have not diminished the supremacy of clinical studies". ${ }^{35}$ In fact, according to him, it remained difficult to bring together in a single description the infections caused by staphylococcus, streptococcus or pneumococcus, when these germs were found in diseases as varied as bronchitis, pneumonia, infective endocarditis, meningitis, etc. Electing the microbial etiology as the nosographical basis would result in a mistake: unifying dissimilar clinical findings and dividing obvious symptomatic groupings.

Bouchard devised a pathogenic classification of affections in which the following appeared: "primary elementary dystrophies", "primary nutritional disorders", "nervous reactions" and "infectious diseases". He commented that all classifications contained excellent elements, but were open to criticism because of their artificial

\footnotetext{
${ }^{32}$ Le Gendre, op. cit., note 10 above, pp. 185-96.

${ }^{33}$ Charles Bouchard, Actions des produits sécrétés par les microbes pathogènes, Paris, Gauthier-Villars, 1890, pp. 6, 12, 21, 25 and 48;
}

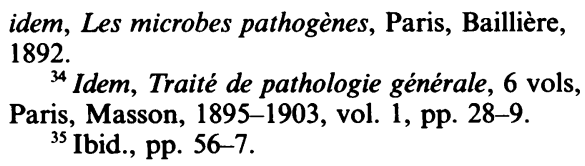




\section{Alain Contrepois}

character. He pointed out the singular existence of one morbid group, "infectious diseases", whose emergence to autonomy had been remarked by observers for many years. In this group, he clearly distinguished between "specific infectious illnesses" with well-defined characteristics, whose etiology amounted to "determining the morbid group", and "non-specific infectious diseases" caused by various microbes (often "common" bacteria living in skin and mucous membranes), which gave rise to various clinical manifestations, given below. Yet, the dominant element in the nosographic study remained the "morbid localization". ${ }^{36}$ Bouchard's classification was as follows:

\section{INFECTIOUS DISEASES}

Specific. These diseases could be of: (1) bacterial origin (typhoid, carbuncle, glanders, cholera, dysentery, plague, diphtheria, blennorrhagia, soft chancre, flu, dengue, whooping cough, mumps, syphilis, leprosy, tuberculosis, bacterial pseudotuberculoses); (2) vegetal origin (actinomycosis, botryomycosis, aspergillosis); (3) animal origin (malaria, trichinosis); or (4) unknown origin: fevers associated with eruptions such as yellow fever, rabies, exanthematous typhus, acute articular rheumatism, cancers and neoplasms, leukocythemia). Non-specific (bacterial origin). This group of diseases included: (1) septicaemias and pyemias, and (2) exudative, suppurative, degenerative, pseudomembranous, ulcerous, and gangrenous inflammations (organs, tissues, systems).

\section{ParasitiC Diseases}

These afflictions could be of: (1) bacterial origin (?); (2) vegetal origin (trichophytosis, favus, alopecia areata, pityriasis versicolor); or (3) animal origin (taenia, Bothriocephalus (pseudophyllid tapeworm), hydatid cyst, ascarids, oxyuris, scabies, pediculosis). ${ }^{37}$

Thus, between Grisolle's 1862 classification and that of Bouchard published in 1903, a broad range of infectious diseases that constitute the field called in France "pathologie infectieuse" had been recognized and categorized. Grisolle put smallpox and measles with "fevers"; mumps and roseola with "inflammations"; rabies, carbuncle, and syphilis with "poisonings"; and leprosy, phthisis and tubercles with "organic transformations and pathological morbid products". ${ }^{38}$ Bouchard put all these afflictions into a single class-"specific infectious diseases", which were always caused by the same germ. Concerning the group of specific infectious diseases of "unknown origin", he specified that, "For the moment, even though we have not succeeded ... in detecting their pathogenic agents, we are sure that they are very

\footnotetext{
${ }^{36}$ Ibid., pp. 60-5.

${ }^{37}$ This classification closely resembles that used at the end of the twentieth century; the major difference is that the infectious diseases of
}

\footnotetext{
"unknown origin" according to Bouchard are now generally attributed to viruses.

${ }^{38}$ Grisolle, op. cit., note 7 above, pp. $877-82$ and 1003-10.
} 
close to specific infections". ${ }^{39}$ This etiological classification of infectious diseases was made possible by the development of microbiological techniques in parallel with the evolution of clinical practice. For non-specific infectious diseases, Bouchard noted the major clinical infectious syndromes: local and local-regional inflammations corresponding to Grisolle's class of "inflammations".

Based on the evolving "microbial theory", physicians brought to the clinical and experimental study of antiseptics a qualitative change- these agents were henceforth progressively etched into the rationale of therapeutic rules that took into account in vitro findings, the toxicity of the products in animals and the "pharmacological" data obtained in patients.

\section{Antimicrobial Chemical Therapy with Antiseptics}

Historians of medical antimicrobial therapy have studied the relationships between science and treatment, either from the point of view of Pasteurian sera and vaccines in France, ${ }^{40}$ or the German chemical stance of Paul Ehrlich (1854-1915), the founder of antibacterial "chemotherapy". ${ }^{41}$ But these historical studies have often neglected the attempts made by hospital physicians experimenting with antimicrobial treatments. Following the example of Charles Bouchard, professor of pathology and general therapeutics, hospital clinicians plunged headlong into medical antiseptic therapeutics in tandem with surgical and obstetrical antisepsis. ${ }^{42}$ Of course, they knew the work

\footnotetext{
${ }^{39}$ Bouchard, op. cit., note 34 above, p. 61.

${ }^{40} \mathrm{See}$, in particular, Dagognet, op. cit., note 2 above; Pierre Darmon, Pasteur, Paris, Fayard, 1995; Patrice Debré, Louis Pasteur, Paris, Flammarion, 1995; René Dubos, Louis Pasteur, Paris, PUF, 1955 (reprinted, Paris, La Découverte, 1995); Gerald L Geison, The private science of Louis Pasteur, Princeton University Press, 1995; Moulin, op. cit., note 5 above; AnneMarie Moulin (ed.), L'aventure de la vaccination, Paris, Fayard, 1996; Salomon-Bayet, op. cit., note 2 above; Maurice Vallery-Radot, Pasteur, Paris, Perrin, 1995. On therapeutics during the nineteenth century, see Vogel and Rosenberg (eds), op. cit., note 4 above; J H Warner, The therapeutic perspective in medical practice, knowledge and identity in America, 1820-1885, Cambridge, MA, Harvard University Press, 1986.

${ }^{41}$ Georges Canguilhem, 'L'effet de la bactériologie dans la fin des "théories médicales" au XIXe siècle', in Idéologie et rationalité dans l'histoire des sciences de la vie, op. cit., note 6 above, pp. 70-2.

${ }^{42}$ Among clinical doctors, see, in particular, those mentioned in the book on antiseptic
}

therapeutics by Paul Le Gendre, Barette and G Lepage, Traité pratique d'antisepsie appliquée à la thérapeutique et à l'hygiène, Paris, Steinheil, 1888; and that of Charles Bouchard, Thérapeutique des maladies infectieuses, Paris, Savy, 1889: B Abadie, Arthaud, Barette, L Bergeon (Lyons), F A J Berlioz (Grenoble), P Budin, C Burlureaux, L Charpentier, L J Colin, G J Coupard, M E Courtois-Suffit, L Coze (Nancy), L David, M Debove, G Déclat, A J Descroizilles, Desesquelles, G Dieulafoy, DubousquetLaborderie, G Dujardin-Beaumetz, V Feltz (Nancy), C Fernet, Filleau, L Garnier, E Gaucher, J C A Gayet, A N Gilbert, H Gimbert (Cannes), Gingeot, Gohier, Gougenheim (Lyons), Guerder, J Grancher, F Guyon, F Hallopeau, V Hanot, H Hérard, Hiller, Hirtz, S Jaccoud, G Jousset de Bellesme, É Lancereaux, P Le Gendre, A Legroux, Lepage, R Lépine (Lyons), E Main, $\mathbf{P}$ Miquel, Moizard, P Panas, C Paul, Picot (Bordeaux), A Pinard, P Potain, F Raymond, Ritter (Nancy), H G Roger, Ruault, Rueff, Salet, Ségalas, Sevestre, Simon (Nancy), C Talamon, O Tapret, É-L Trouessart, Truc (Lyons), Verneuil, A Weil. 


\section{Alain Contrepois}

of Joseph Lister, who introduced his method of antisepsis to eliminate the presence of germs from wounds and surgical operations. ${ }^{43}$

On 3 August 1877, the Gazette Hebdomadaire published an article entitled, 'Notes on the use of real creosote for the treatment of pulmonary phthisis', by Bouchard (then working at the Bicêtre Hospital) and Gimbert (in Cannes). ${ }^{44}$ They had met in Charles Robin's laboratory, where Gimbert prepared drugs. ${ }^{45}$ In 1877 , the germ responsible for tuberculosis had not yet been identified, but Bouchard and Gimbert had been prescribing "antiputrifactive" creosote empirically to treat "consumptive and phthisical" patients since $1874 .{ }^{46}$ This smelly antiseptic had long been used and was distilled from wood tar after carbonization. In 1870, C A Wurtz estimated that many commercially available creosote preparations contained only phenol or a mixture of phenol and cresylol. ${ }^{47}$

Because Bouchard considered the treatment of tuberculosis to be the major problem confronting doctors of his era, he multiplied his therapeutic trials against this disease that "decimated humanity". Bouchard attacked the "tubercle" eight years before Koch isolated the bacillus responsible, but also eight years after the

\footnotetext{
${ }^{43}$ Joseph Lister, 'On the antiseptic principle in the practice of surgery', Lancet, 1867, ii: 353-6; Just Lucas-Championnière, Chirurgie antiseptique, Paris, Baillière, 1876. See also Christopher Lawrence and Richard Dixey, 'Practising on principle: Joseph Lister and the germ theories of diseases', in C Lawrence (ed.), Medical theory, surgical practice: studies in the history of surgery, London and New York, Routledge, 1992, pp. 153-215.

${ }^{44}$ Charles Bouchard, and Henri Gimbert, Note sur l'emploi de la créosote vraie dans le traitement de la phtisie pulmonaire, Paris, Masson, 1877, pp. 1-19. Of course the authors noted that there was already a history of creosote and charcoal use in therapeutics before they turned to them.

${ }^{45}$ Charles Bouchard, Henri Gimbert and Victor Cornil were loyal workers in Charles Robin's laboratory (histology). In addition, Bouchard was Jean-Martin Charcot's student and rapidly became accustomed to laboratory procedures; thereafter, he always associated clinical practice with the laboratory: specimens taken from patients and autopsies of cadavers, their anatomic-pathological examination under the microscope, chemical analyses, etc. P Chalvet, a fully certified medical doctor, staff physician at public hospitals, who died in 1871, had written his doctoral thesis on disinfectants, which undoubtedly contributed to Bouchard's interest in the study of antiseptics (P Chalvet, 'Des désinfectants', MD thesis, Faculty of Medicine, Paris, 1861). Bouchard worked with Chalvet during his residency in the department of Louis Béhier in 1868; Chalvet (a chemist) acquainted him with urology and the chemical analyses of
}

urine. Afterwards, Bouchard systematically analysed urine samples from all the patients in his department.

${ }^{46}$ Charles Bouchard, Opening lecture of 3 December 1872, Gazette Hebdomadaire de Médecine et de Chirurgie, 13 December 1872, no. 50 , pp. 102-7. For Bouchard, in 1872, "empirical" medicine: "limited to the pure recording of observations, led, by means of slow and laborious intellectual process, to the history of the etiology, symptomatology, disease prognoses, to which, by an abuse of language, one opposes scientific medicine ... But, when we examine the physical forces, heat, respiration, urine, sweat, excrements, expectorations, we bring to bear the precision of the instruments of chemistry and physics, and graphic presentation of data. This observational medicine, because of the rigour of the currently applied methods, indeed has the right to be called scientific ... Empirical medicine was able to approach the study of the nature of diseases or morbid relationships ... Systematic medicine cannot function without empirical medicine as a control and moderator."

${ }^{47}$ Charles Adolphe Wurtz, Dictionnaire de chimie pure et appliquée, 2 vols, Paris, 1870, vol. 1, p. 987. Concerning creosote: "It is a strong antiseptic and energetic caustic. At a high dose, it immediately whitens the epidermis and rapidly destroys it; it coagulates blood albumin and egg whites. It is used against dental caries and has been used as a good haemostatic. At the time of its appearance, it benefited from a popularity in medicine as widespread as that of phenol today." 


\section{The Clinician, Germs and Infectious Diseases}

publication of Villemin's studies. In fact, for the treatment of phthisis, he tried to rehabilitate creosote, the medication that Reichenbach had used in the middle of the century. Bouchard and Henri Gimbert attributed the failures that had led to the abandonment of this product to the mode of administration, "illusory or dangerous", or "to an error in the nature of the substance used rather than the medication's lack of efficacy". ${ }^{48}$ Bouchard justified the empirical or even "experimental" use of drugs in phthisis, a severe disease.

Confronted with severe diseases or those reputed to be incurable, experimentation is permissible, some say obligatory. One resists with at least some difficulty the temptation to use new therapeutic agents that, by one of their properties, seem able to fight advantageously against such a harmful element. ${ }^{49}$

Thus, Bouchard had creosote prepared by the pharmacist, $\mathbf{M}$ Mayet, according to Reichenbach's formula, and then by the hospital pharmacy according to that of Georges Dujardin-Beaumetz. ${ }^{50} \mathrm{He}$ studied creosote toxicity in animals and its physiological effects in man before starting clinical trials in phthisical patients. Bouchard and Gimbert administered creosote orally in high doses (up to $3.6 \mathrm{~g}$ per day), which produced, according to them, "in favourable cases, the diminution of expectoration then cough, improvement of physical signs, calming of the fever, restored vigour, attenuation of sweats". ${ }^{51}$ Creosote being a "strong caustic", they renounced using powders, pills and suspensions and chose to use solutions (alcohol solvent) extensively diluted in water or oil (aqueous solutions $1 / 1000$, oily solutions $1 / 100)$. Thus taken, the medication "ceases to be toxic" and its administration is limited only by the "impossibility of the patient to ingest too large quantities of liquid". 52

The authors treated 93 patients with "pulmonary tuberculization" by having them swallow two to four spoonfuls of the mixture per day during a "rather prolonged" period. Although the bitterness of the medication often provoked the "resistance of patients" at the onset, it was well tolerated and was regurgitated "by only one of our phthisical patients". ${ }^{33}$ The results indicated 25 "apparent cures", 29 "improvements", 18 "failures" and 21 "deaths". Even though the authors hoped that the cures were permanent, they preferred the term "apparent cure" because previous experience had shown them several times that these cures were "fragile". ${ }^{54}$ Bouchard took the precaution to conduct a test in a healthy adult for thirty-four consecutive days: every day clinical parameters were recorded (temperature, pulse, respiration, diuresis, appetite, etc.) and chemical analyses of urine were performed (urea, uric acid, phosphoric acid, chloride, colouring agents). No effect of creosote was noted

\footnotetext{
${ }^{48}$ Bouchard, and Gimbert, op. cit., note 44 above, pp. 8-9.

${ }^{49}$ Ibid., p. 1.

${ }^{50}$ Le Gendre, Barette, Lepage, op. cit., note 42 above, p. 286. "Creosoted wine (Bouchard and Gimbert): pure creosote distilled from beechwood $\operatorname{tar} 13.5 \mathrm{~g}$; tincture of gentian $20 \mathrm{~g}$; Montpellier alcohol $250 \mathrm{~g}$; Malaga wine in sufficient quantity to make 1 litre. Creosoted elixir (Dujardin-
}

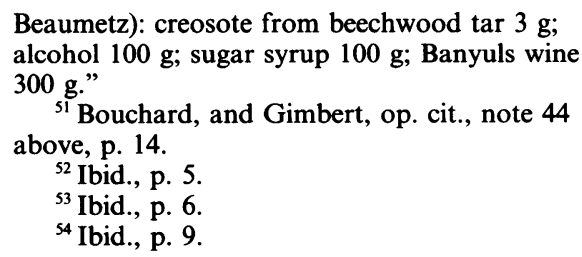

53 Ibid., p. 6.

${ }^{54}$ Ibid., p. 9. 


\section{Alain Contrepois}

in the healthy individual. This was one of the first "clinical trials" of an antiseptic therapy for phthisis. The results of the study were contested and elicited sceptical and even hostile reactions that markedly affected Bouchard.

Under his direction, his students learned to unravel for each particular case the therapeutic indications, based on a careful analysis of the chronological order of "morbid accidents". "What overrides all in therapeutics is knowledge of their indications, which arises from our general notions of the disease and the understanding that we have of the special circumstances surrounding a particular case." 55 Therapeutic principles are determined by the clinical specificities of each individual case. Certainly the therapeutic indications can be multiple, but they do not all carry the same weight. Those that lead to a truly curative action "rely on understanding the major pathogenic principles" ${ }^{56}$ Bouchard attempted, in particular, to introduce the microbial etiology of the infection into the pathogenesis, so that it permeated both clinic and therapy.

During the following years (the early 1880s), Bouchard became highly interested in what was happening in Germany: C Weigert was using aniline to demonstrate the presence of bacteria in tissues; $\mathrm{H}$ Caro had synthesized methylene blue; F $\mathbf{J}$ Cohn was working on the selection of bacterial species by modification of the culture media; Robert Koch was doing research on the carbuncle and the etiology of kidney infections (Leipzig, 1878). He read the Guide for antiseptic treatment of kidney affections, by $\mathrm{J} \mathrm{N}$ von Nussbaum, that had been published in Stuttgart in 1878; he also knew that $\mathrm{A}$ von Bayer had synthesized indigo in 1879, and that $\mathrm{C} \mathrm{J}$ Eberth had isolated the typhoid bacillus the same year. Above all, he was interested in the discovery of the tuberculosis bacillus announced by Koch in $1882 .{ }^{57}$

In 1884, during the International Medical Congress in Copenhagen, Bouchard made known more precisely his opinion concerning the utility of antiseptic treatment of infectious diseases. In contact with surfaces, external or internal (skin, mucosae, abscesses opened by drainage), antiseptics can act slowly and continuously to neutralize little-by-little the germs that form there incessantly; according to him, insoluble chemical agents were preferable. Having established that antiseptics prevented infections in surgery, he then considered the conditions under which these products could be used in medical therapeutics. His starting point was indeed the clinic. Depending upon whether the infection was local or generalized, he considered not only the antibacterial action of antiseptics in vitro, but also the patient's tolerance, the toxicity and the elimination of the drug by the organism.

Within tissues, in humours, the problem appeared arduous for Bouchard: the intruder inhabits the organism but it is impossible to "disinfect" or sterilize the whole body. In this situation, how can one attack the microbe without harming the host? For antiseptics to confront infectious agents, soluble substances, less toxic

\footnotetext{
${ }^{55}$ Le Gendre, op. cit., note 10 above, p. 212.

${ }^{56}$ Ibid., p. 212.

${ }^{57}$ These German studies and authors are cited in different chapters in Bouchard's book
}

published in 1889 (op. cit., note 42 above), along with others, such as Wernich, G Gaffky, F Ziehl, E Klebs, etc., and next to references to the publications of French and English authors. 


\section{The Clinician, Germs and Infectious Diseases}

for tissue cells than for microbes, were needed. ${ }^{58} \mathrm{He}$ was fascinated by the quest for the most appropriate antiseptics in each situation. Disregarding numerous criticisms and objections, he tested a large number of chemical substances. His comprehensive view of the problem of medical therapeutics, led Bouchard, during the early $1880 \mathrm{~s}$, to stress the need to ensure the integrity of renal function before administering active agents which, even at low doses, could become toxic in the context of abnormal kidneys. He carefully studied the conditions of use of quinine, the action of salicylic acid on "renal secretion", the slow elimination of potassium bromide by the kidneys, etc. The questions asked by Bouchard and his clinical practice were very different from those posed at the same time by Pasteur (a chemist) and Émile Roux (a medical doctor). ${ }^{59}$

In the course on general pathology that he taught at the Paris Faculty of Medicine in 1887-88 (published in 1889), Bouchard summarized his ideas concerning the therapeutics of infectious diseases. ${ }^{60} \mathrm{He}$ wondered if bacteriological discoveries had several consequences for drug therapy. He noted that some eminent men resisted the idea that the germ theory could exert an influence on antimicrobial therapy. Several local disinfections were easily accepted for skin, abscesses, and joints, but few physicians attempted to disinfect a uterus or the intestines. As for general antisepsis, it would be "a dream, a chimera, a great illusion". ${ }^{61}$ The fundamental argument was the following, "A substance toxic to a fermentative vegetal cell will always, and even more logically, be toxic to a human nerve cell". ${ }^{62}$

This opinion was almost unanimously expressed by experimenters and even clinicians, and the same objections were heard, according to Bouchard, in the laboratory of physiology at the Sorbonne, in the laboratory of comparative pathology at the Faculty of Medicine, in Pasteur's laboratory and in numerous clinics.

Our adversaries oppose us with the eternal sophism according to which the antiseptic will always kill the patient before killing the microbe. However, we do not necessarily aim at killing the microbe; this task does not belong to us but to the living organism that is fully equipped to cause the death of the microbes. Above all, we want to influence their rampant

\footnotetext{
${ }^{58}$ In this same year (1884) in Germany, Robert Koch also tested a certain number of disinfecting chemical substances in vitro and notably recommended mercuric chloride for disinfecting wounds. Taking the lead from Pasteur's studies on the attenuation of anthrax and chicken cholera germs, he tested certain chemical substances in an attempt to inhibit the growth of the tuberculosis bacillus. Around 1888, he noted the efficacy of certain products in vitro but emphasized the absence of an in vivo therapeutic effect in the tuberculous guinea pig.

${ }^{59}$ Indeed, in 1885 , Pasteur and Roux were working experimentally for the first time on a human pathology, rabies, and on a treatment for this disease that affected a few rare individuals who had been bitten by rabid dogs. The responsible germ had not yet been isolated, and a means of attenuating the "virus" and eliminating
}

its "malignancy" while conserving its integrity remained to be found. Roux and Pasteur finished by suspending the aseptically removed spinal cords of rabid dogs in a flask filled with warm dry air for fifteen days. To test the decline of virulence, they gave rabies to a healthy dog by inoculating it with spinal cord homogenates directly into the brain after trephination. Thus, we enter the realm of experimental pathology, with attenuation of the virus and therapy with a most unusual "vaccine" because it had to treat the disease but not prevent its development. This was a sophisticated and complex experimental biological methodology. The recommended means to combat the disease were not exclusively chemical.
${ }^{60}$ Bouchard, op. cit., note 42 above, p. 5.
${ }^{61}$ Ibid., p. 11.
${ }^{62}$ Ibid., p. 12. 


\section{Alain Contrepois}

proliferation and their ability to function. We block the rapidity of their multiplication, so that there remain fewer to destroy. We can, by diminishing the violence of the infectious agents, give the ailing organism the time to react against them and to resist them victoriously ...63

If quinine triumphs so rapidly and surely against malaria, it is, I think, because it possesses a direct noxious action on the infectious flagellum and not because of a suspected general activity against fevers, for there are many fevers against which quinine is impotent; nor are its antithermal properties at work, since quinine does not lower the temperature of healthy men ... I say that specific medications are the only ones that cure and that the majority of specific agents are antiseptics. Certainly, a sick man can be cured of many diseases without our giving him specific agents; but in such a case, he cures himself alone and the therapeutic means that we use can only, at best, help him cure himself. In contrast, when the cure is truly attributable to the physician, it is because the latter has a specific agent at his disposition. ${ }^{64}$

Bouchard asserted that to assist a patient in this fight against an infectious agent, it is not always necessary to kill the microbe. The organism takes responsibility, so long as it does not have to fight under too adverse conditions; it can manage against a small number of germs, but its resistance drops when confronted with many.

It is almost always impossible to kill, without endangering the patient, the microbes inhabiting the latter; it is possible and often easy to influence the number of microbes by slowing their multiplication. . . ${ }^{65}$ It would be an error to believe that microbes are, in general, our enemies. Indeed, on the contrary, the mass of species of the microbial world are on our side. Without microbes, life would cease to exist on the surface of the earth, it is they who render possible animal and plant life; they are the indispensable intermediaries in the circulation of matter ${ }^{66}$

For Bouchard, what antiseptics do in vitro, they should also accomplish in a wound, in a normal or pathological cavity, in the thickness of a tissue, "What is open to debate is whether antiseptics can slow the proliferation of microbes on or in tissues, not when they are deposited directly, but when they arrive through the circulation." 67

This latter remark clearly shows the importance that Bouchard accorded to the idea of 'General antisepsis', the title of the thirty-third lecture in his course. ${ }^{68}$ According to him, in order to judge the therapeutic value of an antiseptic, it must be established that it shortens the duration and counters the effects of an infectious disease. The argumentation is clearly clinical. But before undertaking trials in patients, he ruled that the antiseptic potency of each chemical substance had to be evaluated in vitro. He devised an "antiseptic-equivalence test" and specified three levels of concentration: one that slowed microbial growth, one that stopped its growth, and one that killed the microbe. Toxicity must also be evaluated in animals ("toxic-equivalence" test) at doses that are innocuous for man. It is not necessary

\footnotetext{
${ }^{63}$ Ibid., p. 315 . The opposition of the Pastorian school to antiseptic medical treatment in infectious diseases was still illustrated in 1894 by Émile Roux: he expressly forbade local antiseptic treatment of sore throats, saying it was "harmful for serum injection" (information reported by Édouard Louis Trouessart, $\mathrm{La}$ thérapeutique antiseptique, Paris, Rueff, 1892, p. 6).
} 
that the antiseptic kill the microbe, it suffices that the substance "diminish or slow its multiplication"; but, most importantly, the antiseptic must not be toxic. With Bouchard's investigations, we witness the birth of the clinical pharmacology of antiseptics.

Bouchard presented his results in table form with antiseptic equivalents of several antiseptic substances determined in vitro against four microbes (typhoid bacillus, Staphylococcus aureus, carbuncle bacterium, pneumococcus). The following antiseptics were tested: naphthalene, iodoform, salol, mercuric chloride, mercuric iodide, creosote, phenol, thymol, resorcinol, naphthol, $b$-naphthol, methylnaphthol.

To determine therapeutic and toxic equivalents, he injected doses intravenously. The dose he sought to identify was not the one introduced here or there in the organism, but the one that was distributed throughout the tissues at the moment that the first physiological effect appeared. One must know not only what was introduced into the body or ingested, but what was really absorbed and present when intoxication accidents arose. To avoid the disadvantages of the digestive tract and subcutaneous routes, Bouchard retained for experiments the intravenous route via a peripheral vein. By this means, he surmised that the antiseptic substance would be distributed instantly and uniformly throughout the organism.

These experiments should be conducted on the same animal species so that the results can be compared; I use rabbits because injection in a marginal ear vein is easy to do. It is necessary to inject the product rapidly (approximately 2 seconds) and the volume to be injected should not be too large. I recommend sterilized water containing sodium chloride $(7 \mathrm{~g} / \mathrm{l})$ as the dissolving liquid. ${ }^{69}$

Therefore, "therapeutic" equivalents were the doses at which the medications started to "act" without the risk of being toxic. Thus, practitioners distinguished between antiseptics for "external" (skin, wounds), "local" (mucosae, cavities) and "general" use.

External use: mercuric chloride and other mercuric preparations, potassium permanganate, ethyl alcohol, silver nitrate for the eyes, iodoform for wound dressings and suppurating surfaces, certain dyes, tincture of iodine. Some of these substances had already been used for a long time.

Local use (mouth, throat, nose, ears, vagina, etc.): dyes like aniline or fuchsin (they were also used "internally" for the treatment of albuminous nephritis; they colour urine red but are well tolerated); 5 per cent resorcinol solution for swabbing, gargling and spraying sore throats, and as a salve (10 per cent) for skin diseases: "styrone" (a derivative of dioxybenzols) used to treat middle ear infection; camphored and "sulforicinated" naphthol for swabbing simple and pseudomembranous sore throats and furunculoses.

In the intestinal canal: insoluble or poorly soluble antiseptics, such as naphthol, naphthol salicylate and benzonaphthol, combined or not with bismuth salicylate, for gastro-enteritis.

General or internal use: quinine was used to treat malaria (classed with the specific antiseptics); naphthalene, $b$-naphthol and creosote for other infections.

${ }^{69}$ Ibid, p. 220. 


\section{Alain Contrepois}

At the end of some medical charts or between the lines of a description of particular administration modes for antiseptic substances, it is possible to detect a taste for "radical" warfare against germs: the aim is the "extermination" of the germ, regardless of the difficulty for the patient. They prescribe, for example, parenchymatous injections, certainly painful for the patient. At the same time, this type of treatment sometimes assumed the aspect of a sort of necessary atonement. Did the patients, perhaps in a desperate quest for new remedies, eagerly seize as their own the idea of a medicinal "antidote" against the infecting agent in which the doctors put their trust: a specific remedy with the ability to destroy effectively the disruptive germ?

The disease was no longer considered a divine punishment for which each individual felt more or less responsible. The "invention" of microbes seemed to relax patients in the sense that it freed them of guilt. But, on the other hand, it filled the known universe with powerful and invisible enemies-defining a hostile and threatening world. The medication was a new rational chemical weapon used for a specific task. It raised high expectations in the prescriber and the treated patient.

When Bouchard suggested antisepsis of the lungs, it was a step on the path towards general antisepsis, towards the battle against infectious agents everywhere in the organism, in blood and tissues. At the end of the century, it was accepted that bronchitis and pneumonia were generally caused by pneumococci or streptococci, and that antiseptic therapy was required. To achieve antiseptic penetration directly into the respiratory apparatus, Bouchard proposed inhalations and sprays that had been used for a long time, and interstitial or parenchymatous injections into the lungs. ${ }^{70} \mathrm{He}$ also attempted to convey the antiseptic directly to the lungs through the general circulation by introducing it into the digestive tract, injecting it into subcutaneous tissues or into the rectum, or even achieving penetration into the blood by pulmonary absorption.

In several patients, he used long Pravaz needles plunged two or three centimetres through an intercostal space to deliver to the pulmonary parenchyma sodium benzoate, concentrated potassium iodide, naphthol or mercuric chloride. The medication penetrated into some "intimate" regions at the interior of the organism and it is difficult to imagine what the patients felt: probably both pain and perhaps a sort of rupture of their bodily integrity because of the violent penetration and sharpness of the needles. An alien substance that could not be digested or rejected had been deposited within them. But their illness had to be very severe for such extreme treatment to be given. Bouchard admitted that more studies would be needed before the procedure could be used routinely in practice. In the meantime, he prescribed orally-administered general antisepsis with naphthol, naphthol salicylate, benzonaphthol, etc.

He attempted local antiseptic treatment of acute pneumonia with interstitial injections, but encountered formidable obstacles: haemoptysis and pneumothorax.

\footnotetext{
${ }^{70}$ Concerning inhalations and sprays, see, in particular, Georges Weisz, 'Academic debate and therapeutic reasoning in mid-19th century France', in Ilana Löwy (ed.), Medicine and
}

change: historical and sociological studies of medical innovation, vol. 220, Paris, INSERM, and London, J Libbey, 1993, pp. 303-11. 


\section{The Clinician, Germs and Infectious Diseases}

According to him, an insoluble antiseptic would have the advantage of fighting against the infectious process by its constant contact. "I gave injections of naphthol in an alcohol solution but only to healthy animals."71 Furthermore, to obtain antisepsis of the airways, Bouchard used medications that, introduced into the blood either by the digestive tract or other routes, "carry out general antisepsis first and then local antisepsis, when the blood brings them to the lungs, and they are eliminated by the alveolar surface or the glands of the bronchial mucosa". ${ }^{72}$

For pulmonary tuberculosis, other than aerotherapy, Bouchard first used vaporization and spraying (a vaporized solution of creosote in alcohol and glycerine) to bring antiseptics into contact with the deep parts of the respiratory apparatus. However, he realized that the medication undoubtedly did not penetrate into the lung in the form of liquid particles and that the favourable effect obtained was probably a result of the saturation of the air with the creosote vapour. Gimbert, for his part, vaporized the patients' rooms overnight with approximately $30 \mathrm{~g}$ of creosote in a bath of heated water. In this way, he "obliged" his patients to inhale the substance, "so that it penetrated into the blood across the pulmonary parenchyma", ${ }^{73}$ and he thought this approach could obtain local and general therapeutic antisepsis at the same time. Some physicians also sprayed turpentine or eucalyptus oil (it is worth noting the continuing importance of a disinfecting odour).$^{74}$

However, Bouchard thought that external means of treatment were insufficient for a disease as profound as tuberculosis. It was important to act within the parenchyma. To obtain antisepsis of bronchi and lungs, he considered pouring solutions directly into the bronchi by puncturing the trachea, rather than using sprays. But preliminary experimental studies were far too inadequate to permit this mode of administration to humans. "Into the trachea of rabbits, I injected $b$ naphtholated $(0.2 \mathrm{~g} / \mathrm{l})$ saline $(7 \mathrm{~g} / \mathrm{l})$ at a flow rate of $10 \mathrm{ml} / \mathrm{kg} /$ hour. This administration did not provoke any problems but must be tested in animals with a pulmonary infection." 75

Robert Koch had already announced his discovery of the tuberculosis bacillus ten years earlier when Edouard Louis Trouessart published his book on antiseptic therapeutics. ${ }^{76}$ For Trouessart, who constantly referred to Bouchard's studies, tuberculosis was difficult to cure because of its slow and insidious evolution, and the localization of tubercles in the pulmonary parenchyma. An "energetic" treatment was necessary: iodoform pills alone or associated with creosote. ${ }^{77}$ Pills or granules seemed to represent the ultimate stage of concentration and purification of a crude

\footnotetext{
${ }^{71}$ Bouchard, op. cit., note 42 above, p. 267.

${ }^{72}$ Ibid., p. 267.

${ }^{73}$ Ibid., p. 261.

${ }^{74}$ In this context, I recommend: Alain Corbin, Le miasme et la jonquille: l'odorat et l'imaginaire social (XVIIIe-XIXe siècle), Paris, Aubier Montaigne, 1982.

${ }^{75}$ Bouchard, op. cit., note 42 above, p. 265.

${ }^{76}$ Trouessart, op. cit., note 63 above. Recommended reading: Charles Burlureaux, $\mathrm{La}$
}

\author{
pratique de l'antisepsie dans les maladies \\ contagieuses, Paris, Baillière, 1892. \\ ${ }^{77}$ Trouessart, op. cit., note 63 above, p. 144. \\ The protocol for the preparation of 100 pills was \\ as follows: creosote + iodoform $5 \mathrm{~g}$; benzoic acid \\ + larch terebinthinate $2 \mathrm{~g}$; powdered \\ marshmallow + magnesia $6 \mathrm{~g}$ (4 to 10 pills per \\ day).
}




\section{Alain Contrepois}

material, the power of miniaturization. In addition, pills had the virtue of being rapidly and totally assimilated; it sufficed to swallow them with a little water. The same year (1892), in England, Thomas Lauder Brunton thought it possible "that amongst the enormous numbers of antiseptic compounds we may yet expect to find many drugs which may be useful as disinfectants in the blood and tissues" ${ }^{78}$

However, creosote toxicity was a source of uneasiness for physicians who also had reservations about certain methods of administrating this substance: Charles Fernet, for example, decided to forego "stomachal ingestion" of creosote because of its "disagreeable" taste and its "irritant action on the gastric mucosa and the dyspepsia which could result". ${ }^{79}$ Thus, according to this staff physician at the Hôpital Beaujon, one had to admit that creosote was not a panacea. He hoped a "truly effective" vaccine or remedy would be found. ${ }^{80}$ Many other doctors at this time denounced the misleading seduction of chemical therapy for tuberculosis and preferred aerotherapy, diet and rest.

For oral administration, Bouchard dissolved the antiseptic in oil, and the patient swallowed one or two spoonfuls morning and evening. Because cod liver oil was often even more disagreeable than the medication, Bouchard sometimes used beechnut oil. He paid attention to the tastes of each patient. "One of my patients had the idea of using butter as the excipient. He took the medication in voluminous pellets enveloped in unleavened bread." medication in this manner to other patients in his ward.

Antisepsis of the digestive tube seems to have preoccupied Bouchard for a long time. According to him - but it was a widespread idea-from the mouth to the anus, the digestive tube was a receptacle for poisons. Metchnikoff even saw it as the reason for the shortness of human life. The typical example was the intestine of typhoid patients and Bouchard conducted various trials to find medications that, without being too irritating or toxic, could be administered to these patients to disinfect their stools. The microbe of typhoid fever had been identified: Eberth's bacillus (discovered in 1879 and isolated in culture by G Gaffky in 1884). Bouchard could only "hope to disinfect the large intestine" by first obtaining antisepsis of the upper portions of the digestive tube. He initially had the patients ingest a mixture of charcoal and sulphur. Small doses of the antiseptics had to be taken frequently, every three to four hours. He prepared a suspension of charcoal and sulphur in glycerine, but this mixture was hardly appetizing. Prostrate typhoid patients swallowed the concoction slowly and incompletely.

\footnotetext{
${ }^{78}$ Thomas Lauder Brunton, An introduction to modern therapeutics, London, Macmillan, 1892, p. 80 , cited by William F Bynum, 'Chemical structure and pharmacological action: a chapter in the history of 19th century molecular pharmacology', Bull. Hist. Med., 1970, 44: 518-38, p. 535.

${ }^{79}$ Charles Fernet, 'De la créosote dans le traitement de la tuberculose pulmonaire',
}

Bulletins et Mémoires de la Société médicale des Hopitaux de Paris, session of 14 February 1896, pp. 1-11. See also J Schmitt, Diagnostic et traitement des maladies infectieuses, Paris, Baillière, 1902, pp. 261-82.

${ }^{80}$ Fernet, op. cit., note 79 above, p. 11.

${ }^{81}$ Bouchard, op. cit., note 42 above, p. 292. 


\section{The Clinician, Germs and Infectious Diseases}

Paul Le Gendre related that visitors to the wards were surprised to see the patients' mouths and chins smeared with the black or yellow mixture. ${ }^{82}$ This was even made the brunt of jokes by interns and residents in other wards. But Bouchard obliged the visitors to attest to the fact, by having them smell the bedpans, that the diarrhoea of these typhoid patients was as odourless as it was black, and that, under the microscope, the numbers of bacteria present in smears of these stools decreased along with their deodorization. The patient's tongue was perhaps black, but it was humid and the abdomen was soft.

Bouchard's experiments tested a series of insoluble or poorly soluble chemical agents that were reputed to be disinfectants. In 1889, Bouchard wrote,

At the Copenhagen Congress, I formulated the principles of true antisepsis of the digestive tube. The antiseptic must be insoluble, so as not to be gradually absorbed as it continues its route, and so that it can exert its action along the entire length of the intestine to the anus. For a long time, naphthalene, despite its disadvantages, was my preferred antiseptic; I replaced it with $b$-naphthol. ${ }^{83}$

For the patients, taking these medications was undoubtedly very difficult. The odour of naphthalene is repulsive and its taste is caustic; it can be swallowed only when embedded in unleavened bread, i.e., in the form of a "pellet". But some experiments showed that naphthalene could induce cataracts in rabbits and this therapy was discontinued.

For Bouchard, $b$-naphthol did not have the disadvantages of naphthalene. In humans, a dose of $1.5 \mathrm{~g}$ was needed to obtain adequate antisepsis in ordinary cases; for typhoid fever, $2.5 \mathrm{~g}$ were needed. "I have even given 4 to $6 \mathrm{~g}$ without side effects. ${ }^{" 84} \mathrm{He}$ divided the daily dose into 0.5 -g fractions. Here again, he prepared the dose in a pellet of unleavened bread to protect the buccal and pharyngeal mucosae from direct contact, which provoked an "intense burning sensation". When antisepsis had to be obtained as rapidly as possible, Bouchard was able to achieve "complete deodorization of the stools" in three hours, by shortening the time interval between doses..$^{85}$ Bouchard retained the mixture of $b$-naphthol and bismuth salicylate for digestive tube antisepsis.

This therapeutic research, conducted in the laboratories integrated with the hospital departments, reinforced the continuity between the patient's bed and the laboratory. Clinical treatment of infectious diseases with antiseptics became part and parcel of a complex medical practice, and there was no reason to make it a competitor of Pasteurian serotherapy; they were two different things. It seems that the role of the clinical contribution to the invention of treatments, for example, had been systematically swept aside.

\footnotetext{
${ }^{82}$ Le Gendre, op. cit., note 10 above, p. 268.

${ }^{83}$ Bouchard, op. cit., note 42 above, p. 290.

${ }^{84}$ Ibid., p. 292. Sixty years later, we can read in P Lebeau, Traité de pharmacie chimique, 4th ed., Paris, Masson, 1955, vol. 2, pp. 958-60: “ $b$ naphthol has a considerable antiseptic potency and it is not very toxic ... It is prescribed as a gastrointestinal antiseptic, in the form of tablets
}

\author{
or enemas. It is also used to treat typhoid fever. \\ Its prolonged use can cause irritation of the \\ mucosae ... It is also applied as an antihelmintic \\ ... Externally, it is used as an aqueous solution \\ or salve in dermatology to treat acne and \\ eczema." \\ ${ }^{85}$ Bouchard, op. cit., note 42 above, p. 292.
}




\section{Alain Contrepois}

\section{Conclusion}

The "pasteurization of France", which has been an effective analytic tool, has of late turned into a kind of "pasteurization of French medical history". It has cast a long shadow, dominating our research programmes in a way that has obscured important components of French medicine in the Third Republic.

This paper emphasizes the efforts of certain clinicians, who took advantage of their positions and their social prestige, to carry to term a fight for innovation, at the same time as knowledge derived from hospital facilities, usually Parisian, was established. ${ }^{86}$

Charles Bouchard, a clinician and a pathologist, provides an excellent example of the integration of medical bacteriology into the diagnosis and treatment of patients. Bouchard's approach brought together the French anatomoclinical tradition and a more German-influenced germ theory. This clinic of "infectious diseases", ${ }^{87}$ that in France is called "pathologie infectieuse", cannot be considered a simple application of "pastorism" or the only consequence of the Pasteurian "thinking network" described by Bruno Latour. The clinicians constructed "pathologie infectieuse" by taking into account not only the study of bacteria and their virulence, but also the finely honed study of symptomatology of infections at the bedside, diagnostic research (the tools used were above all those of German bacteriological medicine), perfection of sampling techniques used to "track" germs, establishment of laboratories directly associated with medical units, and therapeutic research.

It therefore seems somewhat unjust to say that medicine harvests the fruits to which it holds no title, and it is difficult to conceive of the production of bacteriological knowledge that owes nothing to medical theories.

\footnotetext{
${ }^{86}$ Erwin H Ackerknecht, Medicine at the Paris hospital, 1794-1848, Baltimore, Johns Hopkins Press, 1967.

${ }^{87}$ It took until 1918 to create a theoretical chair of bacteriology associated with a clinical
}

chair for infectious diseases at the Paris Faculty of medicine. On this subject, see G Weisz, The medical mandarins: the French Academy of Medicine in the nineteenth and early twentieth centuries, Oxford University Press, 1995. 